\title{
Does Resistin Gene Polymorphisms +299 (G>A) Participate in Insulin Resistance in Egyption Non-obese Type 2 Diabetes?
}

Osama KhaliI ${ }^{1}$, Alsayed Alnahal ${ }^{1 *}$, Mohamed Ghonium¹, Samy Fawzy², Magdy Ibrahem ${ }^{2}$, Nermin Raafat $^{2}$ and Walaa Samy ${ }^{2}$

${ }^{1}$ Department of Internal Medicine, Zagazig University Hospital, Egypt

${ }^{2}$ Department of Medical biochemistry, Zagazig university Hospital, Egypt

\begin{abstract}
Background: Insulin Resistance (IR) is a condition which precedes the development of type 2 diabetes mellitus (T2DM). Resistin is a hormone secreted by adipocytes. Resistin gene (RETN) polymorphisms has been found to be associated with obesity and insulin resistance. We choose 60 patients have known type 2 diabetes mellitus against 45 healthy subjects to investigate the relationship between RETN +299 gene polymorphisms and insulin resistance,
\end{abstract} in non-obese patients with T2DM.

Results: The present study revealed statistically significant increase in AA and combined GA+AA genotypes (with ODD Ratio 4.04 and 4.75 respectively), and statistically significant decrease in GG genotype in non-obese T2DM as compared to the control subjects. Also we found statistically significant increase in A allele and serum resistin in T2DM group as compared to the control group. In addition there were statistically significant increase in mean value $\pm \mathrm{SD}$ of fasting blood glucose, insulin, $\mathrm{HOMA}-\mathrm{IR}, \mathrm{HbA} 1 \mathrm{C} \%$, Resistin, total cholesterol, triglyceride, LDL-C and statistically significant decrease in mean value $\pm S D$ in serum HDL-C in AA combined $A A+G A$ subgroups as compared to GG subgroup of T2DM group.

Conclusions: Our study has shown that resistin $+299 \mathrm{G} / \mathrm{A}$ is an important genetic regulator that resulted hyperresistinemia and subsequently may be predisposing factor the development of T2DM in non-obese Egyptian population.

Keywords: Resistin gene polymorphism; Insulin resistance; Type 2 diabetes mellitus

\section{Introduction}

In 2010, 285 million people had been diagnosed with diabetes mellitus worldwide, a prevalence of $6.4 \%$. This is predicted to increase to 439 million, a prevalence of $7.7 \%$ by 2030 [1]. The number of deaths indirectly linked to diabetes mellitus is estimated to be 3.96 million per year for all age groups, a prevalence of $6.8 \%$ [2].

Insulin resistance is an early and strong determinant of T2DM. According to the American Diabetes Association 2013 guidelines, insulin resistance and persistent hyperinsulinemia are found in a variety of medical conditions, including dyslipidemia and hypertension $[3,4]$.

Resistin is a peptide hormone highly expressed in mouse adipose tissue [5]. Expression of resistin appears to increase along with adipocyte differentiation [6]. In humans, the expression pattern of resistin is not totally consistent with the expression in mice and resistin is known to be expressed at higher levels in pre-adipocytes than in mature adipocytes [7]. In addition to fat tissue [8] resistin is also expressed in human peripheral blood monocytes [9].

Resistin has been shown to cause "high levels of Low-Density Lipoprotein (LDL); increasing the risk of heart disease [10]. Resistin increases the production of LDL in human liver cells and also degrades LDL receptors in the liver. As a result, the liver is less able to clear LDLcholesterol from the body. Resistin accelerates the accumulation of LDL in arteries, increasing the risk of heart disease. Resistin adversely impacts the effects of statins, the main cholesterol-reducing drug used in the treatment and prevention of cardiovascular disease [11].

Resistin plays a role in the regulation of energy, glucose, and lipid homeostasis [12] and the maintenance of fasting blood glucose levels [13] by modulating hepatic insulin action [14]. Resistin has low circulating levels [15], but in some studies it has been reported to be upregulated in insulin resistance, T2DM, and Cardiovascular Diseases (CVD) [16].

Some studies have reported increased resistin expression levels in type 2 diabetes mellitus, insulin resistance or obesity, Metabolic Syndrome (MS), and cardiovascular disease [17], while some failed to detect any change in resistin levels in these conditions [18].

Resistin may increase the susceptibility of Metabolic Syndrome (MS) by regulating adiponectin secretion from adipocytes and enhancing hepatic gluconeogenesis by inhibiting the enzymes involved in gluconeogenesis through AMP-activated protein kinase activation [19]. Another study reported that subjects with premature atherosclerosis have higher levels of plasma resistin compared with subjects with established atherosclerosis [20].

Resistin gene (RETN) located on chromosome 19p13.3 and up to $70 \%$ of the variation in serum resistin levels explained by genetic factors. RETN, a gene coding for resistin, is located at chromosome location 19 p13.3 [21]. Several single-nucleotide polymorphisms (SNPs) have been described in the RETN promoter, intron and 3'UTR (un-translated region) regions. Only one non-synonymous substitution (C63R) in the coding region of exon 3 has been reported. Due to its frequency $(<2.0 \%)$, this polymorphism has not been studied further [22].

${ }^{*}$ Corresponding author: Alsayed alnahal, Internal Medicine Department, Zagazig University Hospital, Egypt, Tel: 00201113174798; E-mail: alnahal2002@yahoo.com

Received April 18, 2014; Accepted June 25, 2014; Published July 07, 2014

Citation: Khalil O, Alnahal A, Ghonium M, Fawzy S, Ibrahem M, et al. (2014) Does Resistin Gene Polymorphisms +299 (G>A) Participate in Insulin Resistance in Egyption non-Obese Type 2 Diabetes? Int J Genomic Med 2: 117. doi: 10.4172/2332-0672.1000117

Copyright: $\odot 2014$ Khalil O, et al. This is an open-access article distributed unde the terms of the Creative Commons Attribution License, which permits unrestricted use, distribution, and reproduction in any medium, provided the original author and source are credited. 
Citation: Khalil O, Alnahal A, Ghonium M, Fawzy S, Ibrahem M, et al. (2014) Does Resistin Gene Polymorphisms +299 (G>A) Participate in Insulin Resistance in Egyption non-Obese Type 2 Diabetes? Int J Genomic Med 2: 117. doi: 10.4172/2332-0672.1000117

Page 2 of 7

Results of different studies investigating genetic variations in the RETN were controversial. [23].

The allele and genotype frequencies at several RETN SNPs between subjects with Type 2 diabetes and healthy controls have been compared [24] and no difference has been observed, except in one study. Tan et al. reported that subjects with Type 2 diabetes have more often allele A than allele $\mathrm{G}$ compared with healthy controls in 3'UTR $+62 \mathrm{G}>\mathrm{A}$ $\mathrm{SNP}$ [25]. RETN polymorphisms have also been associated with other obesity-related phenotypes. An association has been found with blood pressure [26], Body Mass Index (BMI), body weight and body fat percentage, serum triglycerides, fasting blood glucose concentration and lower insulin resistance index [24].

Therefore, we aimed to investigate the relationship between RETN +299 gene polymorphisms and insulin resistance, in non-obese patients with T2DM.

\section{Subjects and Methods}

\section{Subjects}

This study is observational, case control study included (105) unrelated subjects recruited from diabetes and endocrinology outpatient clinic of Internal Medicine Department of Zagazig University Hospitals. Subjects were classified into two groups; Group I: include 60 non-obese patients known Type 2 diabetes mellitus (T2DM) and noncomplicated, (31 males and 29 females) with age ranged from 40-60 with a mean value \pm SD of $50.8 \pm 6.33$ years). 24 of them were on anti hyperlipidemic drugs, they were on diet control in addition to oral hypoglycemic drugs. 22 of them received lipid lowering drugs (e.g. statins).Group II: include 45 apparently healthy patients (non-diabetic group) as control group, who were (23 males and 22 females) matched to cases by gender and ethnic origin. We exclude the obese participants with $\mathrm{BMI}>25 \mathrm{~kg} / \mathrm{m}^{2}$, uncontrolled hypertension (BP $\left.>160 / 100\right)$, liver, kidney, thyroid, cardiovascular orany active inflammatory diseases, as well as receiving medications that affect glucose metabolism(except in T2DM group). The ethical committee of Faculty of Medicine, Zagazig University approved our study protocol, and all participants assigned written informed consent.

\section{Methods}

All patients were subjected to thorough history taking including family history of diabetes, complete physical and full clinical assessment including vital signs and anthropometric variables (BMI was calculated as weight in $\mathrm{kg} /$ height in (meters).

Biochemical analysis: Routine investigations which include (Complete blood picture, Liver and Kidney function tests, admission blood glucose (RBG), fasting blood glucose (FBG), HbA1c [7], serum electrolytes, urine analysis, fasting Lipid profile

According to Friedewald formula, LDL cholesterol was calculated from the following [27]: LDL cholesterol $=$ total cholesterol $-(\mathrm{HDL}$ cholesterol +0.47 triglycerides).

\section{Fasting serum insulin by ELISA}

Determination of insulin resistance (IR) by Homeostasis model assessments of insulin resistance (HOMA-IR) were performed and calculated by the following formula: HOMA index $=$ [Fasting insulin $(\mu \mathrm{U} / \mathrm{ml}) \times$ fasting plasma glucose $(\mathrm{mmol} / \mathrm{l})] / 22.5$. Subjects were considered insulin resistance if HOMA was greater than 1.64 [28].

\section{Specific investigations}

a. Serum resistin was measured by ELISA kit provided by (Biosource Europe S.A., Nivelles, Belgium).

\section{b. Genomic DNA extraction}

DNA was isolated and purified from whole blood (EDTA) using QIAamp-spin-columns according to the protocol provided by the manufacturer (QIAamp Blood Kit; Qiagen GmbH, Hilden, Germany). DNA was stored at $-20^{\circ} \mathrm{C}$ till the time of use.

\section{c. Polymorphism analysis of the RETN +299G >A (rs3745367)}

Determination of +299 resistin gene polymorphism by PCR amplification according to Kunnari et al, followed by restriction site enzyme digestion and gel electrophoresis [30] (Figures 1 and 2). An intron variant, at position $+299(\mathrm{G}>\mathrm{A})$ ( $\mathrm{rs} 3745367)$ from a translation start site, in RETN gene was amplified using forward primer 5'-GAGAGGATCCAGGAGGTCG-3' and the reverse primer 5'-GTGAGACCAAACGGTCCCT-3'. The amplification was carried out in a total $50 \mu \mathrm{l}$ volume reaction contained $50 \mathrm{ng}$ of genomic DNA, $0.2 \mu \mathrm{M}$ of each primer (Promega, Madison, WI) and $1 \times$ PCR mix (Taq PCR Master Mix Kit, QIAGEN, GmbH, Hilden, Germany). PCR was

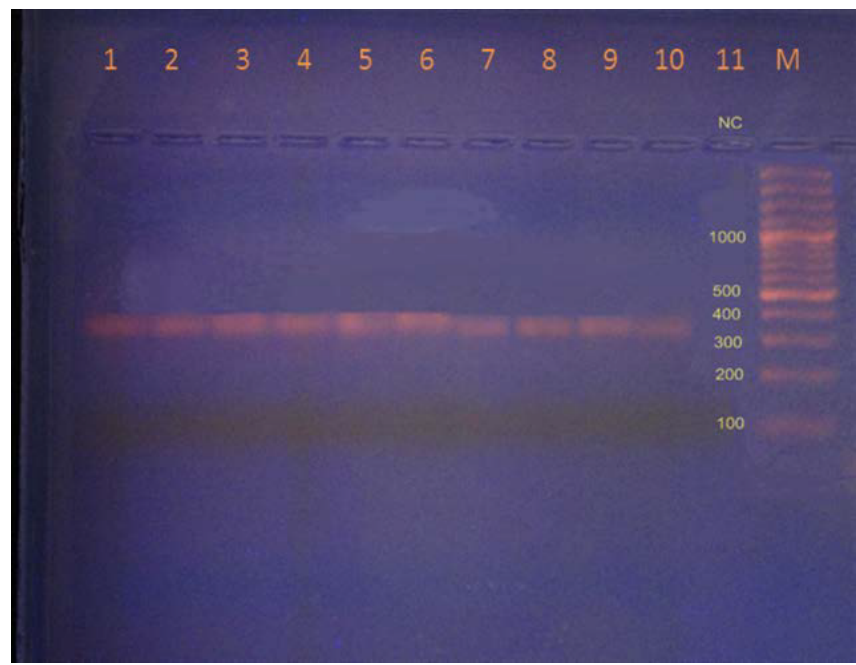

Figure 1: Picture of gel electrophoresis showing amplified PCR product of resistin gene sequence of 373 bp length. NC: Negative control, M: (100 bp $1.5 \mathrm{~kb})$ DNA ladder.

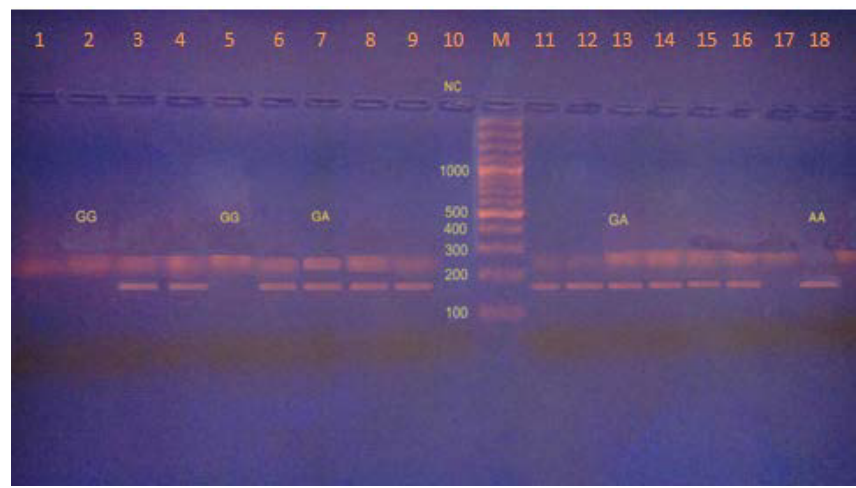

Figure 2: Picture of gel electrophoresis showing G Allele and AAllele variant of +299 G/A resistin gene polymorphism. NC: Negative control, M: (100 bp - 1.5 kb) DNA ladder. 
Citation: Khalil O, Alnahal A, Ghonium M, Fawzy S, Ibrahem M, et al. (2014) Does Resistin Gene Polymorphisms +299 (G>A) Participate in Insulin Resistance in Egyption non-Obese Type 2 Diabetes? Int J Genomic Med 2: 117. doi: 10.4172/2332-0672.1000117

Page 3 of 7

performed as follows: denaturation at $95^{\circ} \mathrm{C}$ for $5 \mathrm{~min}$, preannealing at $59^{\circ} \mathrm{C}$ for $1 \mathrm{~min}$, and then elongation at $72^{\circ} \mathrm{C}$ for $2 \mathrm{~min}$ followed by 35 cycles of $30 \mathrm{~s}$ at $95^{\circ} \mathrm{C}, 30 \mathrm{~s}$ at $59^{\circ} \mathrm{C}$ and $1 \min 15 \mathrm{~s}$ at $72^{\circ} \mathrm{C}$, and elongation at $72^{\circ} \mathrm{C}$ for $10 \mathrm{~min}$. The 173 -bpPCR product was digested with $5 \mathrm{U}$ AluI (MBI-Fermentas, United Kingdom) at $37^{\circ} \mathrm{C}$ for $16 \mathrm{~h}$. The digestion products were separated on a $2 \%$ agarose gel stained with of ethidium bromide to visualize the bands. Quality control measures include blinded analyses and replicates of $10 \%$ of samples, and negative controls for contamination (no DNA) were run routinely with patient samples.

Blood sampling: Five $\mathrm{ml}$ of fasting peripheral venous blood sample were withdrawn from each subject under complete aseptic conditions and divided into 3 portions: $1 \mathrm{ml}$ of whole blood was collected into evacuated tubes containing EDTA, for genomic DNA extraction andHbAlc; $1 \mathrm{ml}$ of whole blood was collected into evacuated tubes containing fluoride for fasting blood glucose. Serum were separated immediately from remaining part of the sample and stored at $-20^{\circ} \mathrm{C}$ until analysis.

Statistical analysis: The results were expressed as the mean \pm $\mathrm{SD}$ and were analyzed using Student's $t$-test, ANOVA. The statistical significances of differences in the frequencies of variants between the groups were tested using the $\chi^{2}$ test. In addition, the Odds Ratios (ORs) and $95 \%$ confidence interval $(95 \% \mathrm{CI})$ were calculated as a measure of the association of the RETN +299G>A genotypes with insulin resistance and development of T2DM.A difference was considered significant at $\mathrm{P}<0.05$. All data were evaluated using statistical package for social sciences (SPSS) for windows version 17.

\section{Results}

Our study included 2 groups: T2DM group which included 60 patients , against 45 healthy subjects (control group), both of them were age and sex matched, no statically significant difference as regards to Body mass index , systolic and diastolic blood pressure as shown in Table 1.

Using student $\mathrm{t}$ - test (unpaired), there were statistically significant increase in the mean value \pm SD of fasting blood glucose, fasting serum insulin, HOMA-IR Total cholesterol ,triglyceride, LDL, HbA1C \% and serum Resistin also statistically significant decrease in the mean value \pm SD of serum HDL between T2DM group and healthy control as shown in Table 1.

In Table 2,we studied distribution of Resistin SNP genotype and alleles in both groups, we found the frequencies of RETN+299 AA genotypes were significantly increased inT2DM patients compared to control group (23(38.4\%) versus 6(13.4\%). Carriers of the AA genotypes were significantly more likely to develop T2DM (O.R=4.041, 95\% $\mathrm{CI}=1.47-11.04, \mathrm{P}=0.004)$. The frequency of the A allele of RETN +299 was increased in T2DM patients as compared to control (62.5\% versus $35.6 \%)$, and this difference was statistically significant $(\mathrm{p}=0.0001)$ A GA genotype frequency was increased in T2DM as compared to

\begin{tabular}{|c|c|c|c|c|}
\hline Parameter & $\begin{array}{l}\text { Control } \\
(n=45)\end{array}$ & $\begin{array}{l}\text { T2DM Patients } \\
(n=60)\end{array}$ & $t$ & $p$ \\
\hline Age (years) & $51.26 \pm 5.54$ & $50.8 \pm 6.22$ & 0.387 & 0.6996 \\
\hline $\begin{array}{l}\text { Gender } \\
\text { Male } \\
\\
\text { Female }\end{array}$ & $\begin{array}{l}20(44 \%) \\
25(56 \%)\end{array}$ & $\begin{array}{l}22(40 \%) \\
28(60 \%)\end{array}$ & & $\begin{array}{c}\text { Chi }=0.32 \\
P=0.32\end{array}$ \\
\hline SBP (mmHg) & $124.2 \pm 4.6$ & $125.1 \pm 4.8$ & -0.94 & 0.534 \\
\hline $\mathrm{DBP}(\mathrm{mmHg})$ & $76.5 \pm 4.1$ & $75.8 \pm 3.8$ & 0.861 & 0.39 \\
\hline B.M.I(kg/m²) & $23.8 \pm 1.02$ & $23.2 \pm 1.8$ & -1.06 & 0.29 \\
\hline Creatinine (mg/dl) & $0.78 \pm 0.152$ & $0.75 \pm 0.13$ & 1.023 & 0.30 \\
\hline Fasting blood glucose (mg/dL) & $89.7 \pm 10.2$ & $195.7 \pm 55.9$ & -14.33 & $<0.001$ \\
\hline Fasting serum insulin $(\mu \mathrm{U} / \mathrm{dl})$ & $7.42 \pm 1.92$ & $12.43 \pm 5.6$ & -6.38 & $<0.001$ \\
\hline Total cholesterol (mg/dl) & $182.32 \pm 16.24$ & $204.8 \pm 33.2$ & 4.89 & $<.001$ \\
\hline Triglycerides (mg/dl) & $180.36 \pm 14.53$ & $205.6 \pm 32.3$ & -5.30 & $<0.001$ \\
\hline LDL (mg/dl) & $100.70 \pm 20.16$ & $121.8 \pm 33.6$ & -3.73 & $<0.001$ \\
\hline HDL (mg/dL) & $45.36 \pm 6.2$ & $40.6 \pm 6.95$ & 3.581 & $<0.001$ \\
\hline HOMA-IR & $1.43 \pm 0.48$ & $3.46 \pm 2.8$ & -5.496 & $<0.001$ \\
\hline HbA1C \% & $5.16 \pm 0.67$ & $9.24 \pm 0.1$ & -10.41 & $<0.001$ \\
\hline Resistin (ng/ml) & $1.34 \pm 0.3$ & $4.5 \pm 1.2$ & -19.59 & $<0.001$ \\
\hline
\end{tabular}

SBP: Systolic Blood Pressure; DBP: Diastolic Blood Pressure

Table 1: Comparison of some socio-demographic data, clinical and biochemical characteristics of the studied subjects.

\begin{tabular}{|c|c|c|c|c|c|c|}
\hline & $\begin{array}{l}\text { Control } \\
(n=45)\end{array}$ & $\begin{array}{l}\text { T2DM Patient } \\
(\mathrm{n}=60)\end{array}$ & $x^{2}$ & $\mathbf{P}$ & $\begin{array}{c}\text { Odd ratio } \\
\text { O.R }\end{array}$ & $(95 \% \mathrm{Cl})$ \\
\hline GG & $19(42.2 \%)$ & $8(13.3 \%)$ & 11.13 & 0.001 & 0.210 & $0.08136-0.5448$ \\
\hline GA & $20(44.4 \%)$ & $29(48.3 \%)$ & 0.154 & 0.69 & 1.169 & $0.54-2.54$ \\
\hline AA & $6(13.4 \%)$ & $23(38.4 \%)$ & 7.96 & 0.004 & 4.041 & $1.47-11.04$ \\
\hline GA+AA & $26(57.8 \%)$ & $52(86.7 \%)$ & 11.3 & 0.0004 & 4.75 & $1.84-12.29$ \\
\hline G allele & $58(64.4 \%)$ & $45(37.5 \%)$ & \multirow[b]{2}{*}{14.87} & \multirow[b]{2}{*}{0.0001} & \multirow[b]{2}{*}{3.021} & \multirow[b]{2}{*}{$1.711-5.332$} \\
\hline A allele & $32(35.6 \%)$ & $75(62.5 \%)$ & & & & \\
\hline
\end{tabular}

Table 2: Frequency and distribution of resistin SNP genotype and alleles frequencies in diabetics' patients and controls. 
Citation: Khalil O, Alnahal A, Ghonium M, Fawzy S, Ibrahem M, et al. (2014) Does Resistin Gene Polymorphisms +299 (G>A) Participate in Insulin Resistance in Egyption non-Obese Type 2 Diabetes? Int J Genomic Med 2: 117. doi: 10.4172/2332-0672.1000117

Page 4 of 7

the control ( $48.3 \%$ and $44.4 \%$ respectively) but this difference was statistically non-significant. In Table 3, we divided each of the control and T2DM into 3 subgroups according to genotype frequencies and we compared the mean value $\pm \mathrm{SD}$ of the biochemical parameters, there were statistically significant difference As regards to mean value \pm SD of fasting blood glucose, fasting serum insulin, HOMA-IR- Total cholesterol, triglyceride, LDL-C, HDL-C, HbA1C \% and serum Resistin in AA subgroups (of T2DM group) as compared to both GG and GA subgroups. As well as there were statistically significant difference when comparing GG and GA subgroups as fasting blood glucose, fasting serum insulin, HOMA-IR, triglyceride, LDL-C, HbA1C \% and serum Resistin. No statistically significant differences were detected as regards to the biochemical parameters when comparing AA, GA, GG subgroups in control group. Using student $t$ test we found statistically significant increase in mean value \pm SD of serum total cholesterol, triglyceride, LDL, fasting blood glucose $(\mathrm{mg} / \mathrm{dL})$ Fasting blood insulin $(\mu \mathrm{U} / \mathrm{ml})$, HOMA-IR, HbA1C \% and serum Resistin, as well as decrease in mean value $\pm \mathrm{SD}$ of $\mathrm{HDL}$ in combined GA+AA subgroup as compared to GG subgroup of T2DM Patients in Table 4. Table 5 showed multiple regression analysis of when resistin gene polymorphism +299 (G>A) was used as dependent variable and, HbAlc, HOMA-IR, cholesterol, triglyceride, HDL-c, as well as LDL-c were taken as independent variables. Our results revealed that RETN serum resistin $(\mathrm{P}=0.001)$, was independently associated with resistin gene polymorphism +299 $(\mathrm{G}>\mathrm{A})$.

\section{Discussion}

Egypt has a high prevalence rate of diabetes $15.56 \%$, with high incidence in urban than the rural areas, and obesity $20 \%$ in urban areas [31].

Up till now, there are contradictions among the results of studies investigating genetic variations in resistin, including Single Nucleotide Polymorphisms (SNPs)

\begin{tabular}{|c|c|c|c|c|c|c|}
\hline & & GG & GA & AA & $F$ value & significance \\
\hline \multirow[t]{2}{*}{ Total cholesterol(mg/dl) } & control & $182 \pm 16.2$ & $180 \pm 17.8$ & $183 \pm 14.56$ & 0.081 & $p=.92$ \\
\hline & T2DM Patient & $185 \pm 23$ & $\begin{array}{c}200 \pm 22 \\
-\end{array}$ & $\begin{array}{c}229 \pm 37 \\
\text { ab }\end{array}$ & 10.27 & $P<0.001$ \\
\hline \multirow[b]{2}{*}{ Triglycerides(mg/dl) } & control & $176 \pm 14$ & $177 \pm 15$ & $181 \pm 13$ & 0.277 & $p=.75$ \\
\hline & T2DM Patient & $186 \pm 18$ & $\begin{array}{c}203 \pm 23 \\
a\end{array}$ & $\begin{array}{c}230 \pm 34 \\
\text { ab }\end{array}$ & 10.55 & $p<0.001$ \\
\hline \multirow[t]{2}{*}{ LDL (mg/dl) } & control & $101.18 \pm 8.21$ & $99.7 \pm 8.3$ & $101.6 \pm 6.39$ & 0.22 & $p=.80$ \\
\hline & T2DM Patient & $\begin{array}{c}103.8 \pm \\
13.2\end{array}$ & $121.6 \pm 11.1 \mathrm{a}$ & $\begin{array}{c}145.9 \pm 23 \\
\text { ab }\end{array}$ & 23.11 & $p<0.001$ \\
\hline \multirow[t]{2}{*}{ HDL (mg/dL) } & control & $45.62 \pm 5.44$ & $44.9 \pm 6.5$ & $45.2 \pm 5.66$ & 0.068 & $p=.93$ \\
\hline & T2DM Patient & $44 \pm 5.4$ & $38.2 \pm 6.3$ & $\begin{array}{c}37.1 \pm 7.2 \\
\mathbf{a}\end{array}$ & 3.56 & $p<0.05$ \\
\hline \multirow{2}{*}{ Fasting blood glucose (mg/dL) } & control & $89.7 \pm 9.2$ & $90.7 \pm 8.2$ & $89.8 \pm 10.5$ & 0.005 & $p=.99$ \\
\hline & T2DM Patient & $172 \pm 45$ & $190.7 \pm 50.9 a$ & $\begin{array}{c}220 \pm 51.3 \\
\text { ab }\end{array}$ & 3.77 & $\mathrm{P}<0.05$ \\
\hline \multirow{2}{*}{ Fasting blood insulin $(\mu \mathrm{U} / \mathrm{ml})$} & Control & $4.4 \pm 1.85$ & $4.5 \pm 1.76$ & $6.0 \pm 1.79$ & 1.93 & $p=0.157$ \\
\hline & T2DM Patient & $6.8 \pm 2.22$ & $\begin{array}{c}11.7 \pm 2.34 \\
\mathbf{a}\end{array}$ & $\begin{array}{c}20.75 \pm 2.44 \\
\text { ab }\end{array}$ & 143.04 & $p<0.001$ \\
\hline \multirow[b]{2}{*}{ HOMA-IR } & Control & $1.07 \pm 0.55$ & $1.21 \pm 0.46$ & $1.29 \pm 0.84$ & 0.76 & $p=0.47$ \\
\hline & T2DM Patient & $2.61 \pm 0.69$ & $\begin{array}{c}5.9 \pm 1.08 \\
a\end{array}$ & $\begin{array}{c}11.27 \pm 2.18 \\
\text { ab }\end{array}$ & 307.23 & $p<0.001$ \\
\hline \multirow[b]{2}{*}{ HbA1C \% } & Control & $5.06 \pm 0.47$ & $5.16 \pm 0.37$ & $5.10 \pm 0.57$ & 0.25 & $P=0.77$ \\
\hline & T2DM Patient & $6.60 \pm 1.23$ & $\begin{array}{c}7.68 \pm 1.58 \\
\mathbf{a}\end{array}$ & $\begin{array}{c}9.68 \pm 2.38 \\
\text { ab }\end{array}$ & 10.41 & $P<0.001$ \\
\hline \multirow[b]{2}{*}{ Resistin(ng/ml) } & Control & $1.30 \pm 0.29$ & $1.29 \pm 0.4$ & $1.32 \pm 0.35$ & .0195 & P 0.98 \\
\hline & T2DM Patient & $2.50 \pm 1.02$ & $\begin{array}{c}3.44 \pm 1.22 \\
\text { a }\end{array}$ & $\begin{array}{c}4.46 \pm 1.6 \\
a b \\
a b\end{array}$ & 7.24 & $P<0.001$ \\
\hline
\end{tabular}

Table 3: Statistical analysis of biochemical parameters in association with genotype distribution in studied groups.

\begin{tabular}{|c|c|c|c|c|}
\hline & GG & AA + GA & T value & p-value \\
\hline Total cholesterol(mg/dl) & $185 \pm 23$ & $215 \pm 30$ & 3.29 & $<0.001$ \\
\hline Triglycerides(mg/dl) & $186 \pm 18$ & $216.5 \pm 29$ & 4.05 & $<0.001$ \\
\hline LDL(mg/dl) & $103.8 \pm 13.2$ & $134 \pm 17$ & 5.77 & $<0.001$ \\
\hline HDL(mg/dL) & $44 \pm 5.4$ & $37.65 \pm 6.6$ & -2.99 & $<0.05$ \\
\hline Fasting blood glucose(mg/dL) & $172 \pm 45$ & $206 \pm 51$ & 2.139 & $<0.05$ \\
\hline Fasting blood insulin $(\mu \mathrm{U} / \mathrm{ml})$ & $6.8 \pm 2.22$ & $16.2 \pm 2.39$ & 11.3 & $<0.0001$ \\
\hline HOMA-IR & $2.61 \pm 0.69$ & $8.85 \pm 1.63$ & 18.76 & $<0.001$ \\
\hline HbA1C \% & $6.60 \pm 1.23$ & $8.68 \pm 1.98$ & 4.044 & $<0.001$ \\
\hline Resistin (ng/ml) & $2.50 \pm 1.02$ & $3.95 \pm 1.41$ & 3.53 & $<0.001$ \\
\hline
\end{tabular}

Table 4: Statistical analysis of biochemical parameters in GG subgroup as compared to combined GA+AA subgroup (in T2DM group). 
Citation: Khalil O, Alnahal A, Ghonium M, Fawzy S, Ibrahem M, et al. (2014) Does Resistin Gene Polymorphisms +299 (G>A) Participate in Insulin Resistance in Egyption non-Obese Type 2 Diabetes? Int J Genomic Med 2: 117. doi: 10.4172/2332-0672.1000117

Page 5 of 7

\begin{tabular}{|c|c|c|c|c|c|c|c|}
\hline \multirow[t]{2}{*}{ Model } & \multicolumn{2}{|c|}{ Unstandardized Coefficients } & \multirow{2}{*}{$\begin{array}{c}\text { Standardized } \\
\text { Coefficients } \\
\text { Beta }\end{array}$} & \multirow[t]{2}{*}{$\mathrm{t}$} & \multirow[t]{2}{*}{ Sig. } & \multicolumn{2}{|c|}{ 95\% Confidence Interval for B } \\
\hline & B & Std. Error & & & & Lower Bound & Upper Bound \\
\hline (Constant) & -1.665 & 1.455 & & -1.144 & 0.258 & -4.585 & 1.256 \\
\hline cholesterol & 0.007 & 0.004 & 0.189 & 1.869 & 0.067 & 0 & 0.014 \\
\hline Triglyceride & -0.003 & 0.003 & -0.083 & -0.848 & 0.4 & -0.01 & 0.004 \\
\hline HDL-C & 0.013 & 0.021 & 0.059 & 0.609 & 0.545 & -0.03 & 0.056 \\
\hline LDL-C & -0.003 & 0.003 & -0.099 & -1.009 & 0.317 & -0.009 & 0.003 \\
\hline HOMA & -0.006 & 0.044 & -0.014 & -0.143 & 0.887 & -0.095 & 0.082 \\
\hline $\mathrm{HbA} 1 \mathrm{c} \%$ & -0.017 & 0.059 & -0.029 & -0.281 & 0.78 & -0.135 & 0.102 \\
\hline Resistin & 0.696 & 0.102 & 0.721 & 6.848 & 0 & 0.492 & 0.9 \\
\hline
\end{tabular}

Table 5: Multiple regression analysis of when resistin gene polymorphism +299 (G>A) was used as dependent variable and , HbA1c, HOMA-IR, cholesterol,triglyceride,HDL-C, as well as LDL-C.

Some authors reported the genetic variant at nucleotide +299 $(\mathrm{G}>\mathrm{A})$ and obesity as a risk factors for T2DM in Caucasians [32]. As well as, some studies have found associations between resistin gene polymorphism, and T2DM. Therefore, the genetic variations of the resistin gene in humans require clarification. Previous studies tried to clarify the functions of resistin and stated that resistin might impair insulin action, glucose tolerance, and decreased glucose uptake in skeletal muscle cells [33].

Previous study found that resistin was highly expressed in human omental and abdominal subcutaneous adipocytes than in adipocytes from the thigh, suggesting a possible role of resistin in obesity related insulin resistance [34]. Most of patients with T2DM were related to obesity and insulin resistance. Some authors stated that serum resistin levels were increased in T2DM subjects [35]. Other studies have reported no association between resistin levels and markers of insulin resistance in T2DM patients [36]. Such findings have been re-tested by this study.

The purposes of the current study were to investigate the possible associations of RETN +299 gene polymorphism with insulin resistance in non-obese subjects with T2DM, and to detect whether this polymorphisms is associated with glucose intolerance. The present study revealed statistically significant increase in AA genotype and combined GA+AA (with ODD Ratio 4.04and 4.75 respectively), and statistically significant decrease in GG genotype in non-obese T2DM as compared to the control subjects, The distribution of +299 resistin allele frequencies $\mathrm{G}$ and $\mathrm{A}$ was $37.5 \%$ and $62.5 \%$ respectively in the diabetic group whereas in the control group was $64.4 \%$ and $35.6 \%$ respectively. There was a statistically significant association of A allele in the diabetic group when compared with the control group $(\mathrm{P}=0.0001)$.

Our results are suggesting an association between the presence of the polymorphism and the presence of T2DM. In agreement with Miyamoto et al. and Suriyaprom et al. who reported an association of RETN +299 with T2DM among Japanese and Thais subjects, respectively [20-23]. Also Tan et al. reported that subjects with Type 2 diabetes have more often allele $A$ than allele $G$ compared with healthy controls [25]. Serum resistin was statistically increased in both AA and GA subgroups as compared to the GG subgroup of type 2 diabetics, also in combined AA+GA subgroup as compared to GG subgroup of diabetic group. Our results agreed with Asano et al. [37] they have shown that the plasma resistin concentration was strongly influenced by the rs34861192 and rs3745368 polymorphisms of RETN in an aged Japanese population. Also this goes in agreement with the results obtained by El-Shal et al. who reported that the frequency of the RETN +299 AA genotype was significantly increased in obese diabetic patients compared to control group, the odds ratio
$(\mathrm{OR}=3.53, \mathrm{P}=0.005)$ suggested an association between the presence of the polymorphism and the prevalence of disease. They revealed that the genotypes and alleles of resistin polymorphisms $+299(\mathrm{G}>\mathrm{A})$ were significantly associated with increased risk of impaired glucose tolerance and T2DM compared to normal glucose tolerant patients [38].

This polymorphism is in an intron, $+299(\mathrm{G}>\mathrm{A})$, which generally has not been considered to have regulatory functions. However, it has been shown that SNPs in the non-coding region, such as the 3'-untranslated gene region, canaffect gene expression [39]. Tsukada et al. said that intron polymorphism of TFAP2B, a susceptibility gene to T2DM, influence adipocytokinegene expression transcriptional activity [40]. Suriyaprom et al. concluded that resistin gene polymorphism at $+299(\mathrm{G}>\mathrm{A})$ maybe a marker in linkage disequilibrium with other polymorphism affecting gene expression and may contribute to increased resistin levels in Thai diabetic subjects, which may be involved in the pathogenesis of type 2 diabetes by impaired insulin action [23].

$\mathrm{Ma}$ et al. demonstrated that, a resistin genotype at position +299 $(\mathrm{G}>\mathrm{A})$ and obesity was a significant determinant of type 2 diabetes risk in Caucasians [32]. Also, the G/A or A/A genotype of SNP +299 G>A was found to be associated with increased risk of metabolic syndrome in a Japanese cohort study [20], but had a protective effect against hypertension in a Finnish population based cohort study [41].

Whereas resistin gene $+299(\mathrm{G}>\mathrm{A})$ was not associated with type 2 diabetes in Japanese subjects [42]. This polymorphism is in an intron, +299 (G>A), which generally has not been considered to have regulatory functions. However, it has been shown that SNPs in the noncoding region, such as the 3 '-untranslated gene region, can affect gene expression [43].

The contradictions of resistin gene polymorphism among different studies might be explained by the different genetic backgrounds or environmental conditions of the population studied [37].

The present study reveals that there was a statistically significant association between hyperglycemia and resistin gene polymorphism at positions $+299(\mathrm{G}>\mathrm{A})$. These findings cope with Suriyaprom, et al. [23].

Conflicting findings between these studies could be due to true differences in allelic association with the disease phenotype in different populations. In agreement with this notion were the differences in allele frequencies of these SNPs in various populations.

Lau CH, et al. demonstrated in their study that SNP+299 G>A at the RETN locus appeared to affect the serum resistin concentration, but their association with the risk of T2DM as well as metabolic risk factors might not be due to alterations in resistin level only, but also 
Citation: Khalil O, Alnahal A, Ghonium M, Fawzy S, Ibrahem M, et al. (2014) Does Resistin Gene Polymorphisms +299 (G>A) Participate in Insulin Resistance in Egyption non-Obese Type 2 Diabetes? Int J Genomic Med 2: 117. doi: 10.4172/2332-0672.1000117

Page 6 of 7

other mechanisms than an effect on serum resistin levels by which $\mathrm{SNP}+299 \mathrm{G}>\mathrm{A}$ at the RETN locus could be involved in the association with susceptibility to T2DM [44].

Resistin circulates in two distinct assembly states, trimers and hexamers, Hexamersis formed by intertrimer disulfide bonds. Ethnicity and metabolic changes possibly modulate resistin action by affecting its assembly states [45].

In this study, a significant increase in indices of insulin resistance (including fasting blood glucose and HOMA index) was increased in T2DM group as compared to control group $(\mathrm{p}<0.001)$. According to genotype in patient group, subjects with AA and combined GA+AA genotypes have a statistically significant increase of fasting blood glucose, serum insulin and HOMA index compared to subjects with GG genotype.

This finding confirmed the results of El-Shalet al. who found a significant increase in HOMA-IR, fasting blood glucose level, serum insulin, among T2DM and obese subjects with GA, AA genotypes of RETN +299 when compared to GG and CC genotypes, respectively [38]. But all subjects of this study with average body mass index, because they were on diet control regimen for treatment of T2DM.

Our results revealed statistically significant increase in $\mathrm{HbAlc}$ (\%) in both AA and GA subgroups as compared to GG subgroup of diabetic group coinciding with uncontrolled diabetes. In summary, we found statistically significant increase in AA and combined GA+AA genotypes, and decrease in GG genotype in non-obese T2DM as compared to the control subjects. As well as statistically significant increase in A allele and serum resistin in T2DM group as compared to the control group. Resistin $+299 \mathrm{G} / \mathrm{A}$ polymorphism is in an intron, which generally has not been considered to have regulatory functions. However, it has been shown that SNPs in the noncoding region, such as the 3'-untranslated gene region, can affect gene expression [46].

In conclusion, the results of our study supported the suggestion thatRETN+299 G>A SNP contributed to increase the susceptibility and the development of type 2 diabetes mellitus. This conclusion is based on the observation that our results among diabetic patients demonstrated elevated fasting blood glucose level, serum insulin level and HOMAIR in both AA /GA carriers of RETN +299. Thismay be considered as genetic biomarker for type 2 diabetes in non-obese with potential impact on the family counseling and management.

Further studies are needed to fully clarify the role of resistin gene in type 2 diabetes, by investigation of other populations including different ethnic groups, how resistin polymorphism at +299 (G>A) affects gene expression and to compare both resistin gene polymorphism and serum resistin level in obese and non-obese patients with T2DM.

\section{Limitation}

This study was carried out on a small sample of type 2diabetes of Egyptiation citizen, and studied RETN +299 only. Some diabetics were not obese due diet regimen after diagnosis of diabetes. A larger study in needed to compare other genetic polymorphism e.g RETN-420, as well as obese and non-obese type 2 diabetes, considering also environmental factor in urban and rural areas in Egypt.

\section{References}

1. Shaw JE, Sicree RA, Zimmet PZ (2010) Global estimates of the prevalence of diabetes for 2010 and 2030. Diabetes Res Clin Pract 87: 4-14.

2. Roglic G, Unwin N (2010) Mortality attributable to diabetes: estimates for the year 2010. Diabetes Res Clin Pract 87: 15-19.

3. Lee SH, Park SA, Ko SH, Yim HW, Ahn YB, et al. (2010) Insulin resistance and inflammation may have an additional role in the link between cystatin $C$ and cardiovascular disease in type 2 diabetes mellitus patients. Metabolism 59: 241-246.

4. Ahrén B, Pacini G (2005) Islet adaptation to insulin resistance: mechanisms and implications for intervention. Diabetes Obes Metab 7: 2-8.

5. Rewers M, Zaccaro D, D’Agostino R, Haffner S, Saad MF, et al. (2004) Insulin sensitivity, insulinemia, and coronary artery disease: the Insulin Resistance Atherosclerosis Study. Diabetes Care 27: 781-787.

6. Way JM, Gorgun CZ, Tong G, Uysal KT, Brown KK, et al. (2001) Adipose tissue resistin expression is severely suppressed in obesity and stimulated by peroxisome proliferator-activated reseptor? agonists. J BiolChem 276: 2565125653.

7. Janke J, Engeli S, Gorzelniak K, Luft FC, Sharma AM (2002) Resistin gene expression in human adipocytes is not related to insulin resistance. Obes Res 10: $1-5$.

8. McTernan PG, McTernan CL, Chetty R, Jenner K, Fisher FM, et al. (2002) Increased resistin gene and protein expression in human abdominal adipose tissue. J Clin Endocrinol Metab 87: 2407.

9. Fain JN, Cheema PS, Bahouth SW, Lloyd Hiler M (2003) Resistin release by human adipose tissue explants in primary culture. Biochem Biophys Res Commun 300: 674-678.

10. Haugen F, Jorgensen A, Drevon CA, Trayhurn $P$ (2001) Inhibition by insulin of resistin gene expression in 3T3-L1 adipocytes. FEBS Lett 507: 105-108.

11. Ukkola O (2002) Resistin - a mediator of obesity-associated insulin resistance or an innocent bystander? Eur J Endocrinol 147: 571-574.

12. Steppan CM, Lazar MA (2002) Resistin and obesity-associated insulin resistance. Trends Endocrinol Metab 13: 18-23.

13. Patel L, Buckels AC, Kinghorn IJ, Murdock PR, Holbrook JD, et al. (2003) Resistin is expressed in human macrophages and directly regulated by PPAR gamma activators. Biochem Biophys Res Commun 300: 472-476.

14. Banerjee RR, Rangwala SM, Shapiro JS, Rich AS, Rhoades B, et al. (2004) Regulation of fasted blood glucose by resistin. Science 303: 1195-1198.

15. Muse ED, Obici S, Bhanot S, Monia BP, McKay RA, et al. (2004) Role of resistin in diet-induced hepatic insulin resistance. J Clin Invest 114: 232-239.

16. Galic S, Oakhill JS, Steinberg GR (2010) Adipose tissue as an endocrine organ. Mol Cell Endocrinol 316: 129-139.

17. Zhang MH, Na B, Schiller NB, Whooley MA (2011) Association of resistin with heart failure and mortality in patients with stable coronary heart disease: data from the heart and soul study. J Card Fail 17: 24-30.

18. Norata GD, Ongari M, Garlaschelli K, Raselli S, Grigore L, et al. (2007) Plasma resistin levels correlate with determinants of the metabolic syndrome. Eur $J$ Endocrinol 156: 279-284.

19. Weisberg SP, McCann D, Desai M, Rosenbaum M, Leibel RL, et al. (2003) Obesity is associated with macrophage accumulation in adipose tissue. $\mathrm{J}$ Clin Invest 112: 1796-1808.

20. Miyamoto Y, Morisaki H2, Kokubo Y2, Yamanaka I2, Tomoike H2, et al. (2009) Resistin gene variations are associated with the metabolic syndrome in Japanese men. Obes Res Clin Pract 3: I-II.

21. Steppan CM, Bailey ST, Bhat S, Brown EJ, Banerjee RR, et al. (2001) The hormone resistin links obesity to diabetes. Nature 409: 307-312.

22. Pizzuti A, Argiolas A, Di Paola R, Baratta R, Rauseo A, et al. (2002) An ATG repeat in the 3'-untranslated region of the human resistin gene is associated with a decreased risk of insulin resistance. J Clin Endocrinol Metab 87: 44034406.

23. Suriyaprom K, Phonrat B, Namjuntra P, Chanchay S, Tungtrongchitr R (2009) The $+299(\mathrm{G}>\mathrm{A})$ resistin gene polymorphism and susceptibility to type 2 diabetes in Thais. J Clin Biochem Nutr 44: 104-110.

24. Osawa $\mathrm{H}$, Onuma $\mathrm{H}$, Murakami A, Ochi M, Nishimiya T, Kato K et al. (2002) Systematic search for single nucleotide polymorphisms in the resistin gene. The absence of evidence for the association of three identified single nucleotide polymorphisms with Japanese Type 2 diabetes. Diabetes 51: 863-866. 
Citation: Khalil O, Alnahal A, Ghonium M, Fawzy S, Ibrahem M, et al. (2014) Does Resistin Gene Polymorphisms +299 (G>A) Participate in Insulin Resistance in Egyption non-Obese Type 2 Diabetes? Int J Genomic Med 2: 117. doi: 10.4172/2332-0672.1000117

25. Tan MS, Chang SY, Chang DM, Tsai JC, Lee YJ (2003) Association of resistin gene 3'-untranslated region +62G-->A polymorphism with type 2 diabetes and hypertension in a Chinese population. J Clin Endocrinol Metab 88: 1258-1263.

26. Engert JC, Vohl MC, Williams SM, Lepage P, Loredo-Osti JC, et al. (2002) 5 flanking variants of resistin are associated with obesity. Diabetes 51: 16291634.

27. Friedewald WT, Levy RI, Fredrickson DS (1972) Estimation of the concentration of low-density lipoprotein cholesterol in plasma, without use of the preparative ultracentrifuge. Clin Chem 18: 499-502.

28. Matthews DR, Hosker JP, Rudenski AS, Naylor BA, Treacher DF, et al. (1985) Homeostasis model assessment: insulin resistance and beta-cell function from fasting plasma glucose and insulin concentrations in man. Diabetologia 28 : 412-419.

29. Kunnari A, Ukkola O, Kesäniemi YA (2005) Resistin polymorphisms are associated with cerebrovascular disease in Finnish Type 2 diabetic patients. Diabet Med 22: 583-589.

30. Kim KH, Lee K, Moon YS, Sul HS (2001) A cysteine-rich adipose tissue-specific secretory factor inhibits adipocyte differentiation. J Biol Chem 276: 11252 11256

31. www.idf.org/diabetesatlas

32. Ma X, Warram JH, Trischitta V, Doria A (2002) Genetic variants at the resistin locus and risk of type 2 diabetes in Caucasians. J Clin Endocrinol Metab 87: 4407-4410.

33. Rajala MW, Obici S, Scherer PE, Rossetti L (2003) Adipose-derived resistin and gut-derived resistin-like molecule-beta selectively impair insulin action on glucose production. J Clin Invest 111: 225-230.

34. McTernan CL, McTernan PG, Harte AL, Levick PL, Barnett AH, et al. (2002) Resistin, central obesity, and type 2 diabetes. Lancet 359: 46-47.

35. Fujinami A, Obayashi $H$, Ohta K, Ichimura T, Nishimura M, et al. (2004) Enzyme-linked immunosorbent assay for circulating human resistin: resistin concentrations in normal subjects and patients with type 2 diabetes. Clin Chim Acta 339: 57-63.

36. Stejskal D, Adamovska S, Bartek J, Jurakova R, Proskova J (2003) Resistin concentrations in persons with type-2 diabetes mellitus and in individuals with acute inflammatory disease. Biomed Pap Med Fac Univ Palacky Olomouc Czech Repub 147: 63-69.

37. Asano H, Izawa H, Nagata K, Nakatochi M, Kobayashi M, et al. (2010) Plasma resistin concentration determined by common variants in the resistin gene and associated with metabolic traits in an aged Japanese population. Diabetologia 53: 234-246.

38. El-Shal AS, Pasha HF, Rashad NM (2013) Association of resistin gene polymorphisms with insulin resistance in Egyptian obese patients. Gene 515 233-238.

39. Pesole G, Mignone F, Gissi C, Grillo G, Licciulli F, et al. (2001) Structural and functional features of eukaryotic mRNA untranslated regions. Gene 276: 73-81.

40. Tsukada S, Tanaka Y, Maegawa H, Kashiwagi A, Kawamori R, et al. (2006) Intronic polymorphisms within TFAP2B regulate transcriptional activity and affect adipocytokine gene expression in differentiated adipocytes. Mo Endocrinol 20: 1104-1111.

41. Ukkola O, Kunnari A, Kesäniemi YA (2008) Genetic variants at the resistin locus are associated with the plasma resistin concentration and cardiovascular risk factors. Regul Pept 149: 56-59.

42. Ochi M, Osawa H, Onuma H, Murakami A, Nishimiya T, et al. (2003) The absence of evidence for major effects of the frequent SNP +299G>A in the resistin gene on susceptibility to insulin resistance syndrome associated with Japanese type 2 diabetes. Diabetes Res Clin Pract 61: 191-198.

43. Tsukada S, Tanaka Y, Maegawa H, Kashiwagi A, Kawamori R, et al. (2006) Intronic polymorphisms within TFAP2B regulate transcriptional activity and affect adipocytokine gene expression in differentiated adipocytes. Mol Endocrinol 20: 1104-1111.

44. Lau CH, Muniandy S (2011) Adiponectin and resistin gene polymorphisms in association with their respective adipokine levels. Ann Hum Genet 75: 370-382.

45. Patel SD, Rajala MW, Rossetti L, Scherer PE, Shapiro L (2004) Disulfidedependent multimeric assembly of resistin family hormones. Science 304 1154-1158.

46. Pesole G, Mignone F, Gissi C, Grillo G, Licciulli F, et al. (2001) Structural and functional features of eukaryotic mRNA untranslated regions. Gene 276: 73-81. 